\title{
Pengaruh Pengetahuan, Motivasi serta Independensi terhadap Kualitas Audit Internal di Bank Perkreditan Rakyat (BPR) Kota Malang
}

\author{
Johanis Nifanngeljau ${ }^{1}$ \\ Sekolah Pasca Sarjan Universitas \\ Merdeka Malan, Indonesia
}

\author{
Ahmad Mukoffi ${ }^{2}$ \\ Universitas Tribhuwana Tunggadewi \\ Malang, Indonesia
}

\section{Surel : jhonnifan05@gmail.com}

\section{ABSTRAK}

Tujuan penelitian ini dibuat untuk untuk dapat menganalisis serta memberikan fakta terkait dengan adanya pengetahuan, motivasi dan indepensi dapat memberikan pengaruh pada kualitas audit dalam penelitian ini berbentuk metodepenelitian survei yang mana akan menggunakan kuesioner dengan cara untuk dapat mengumpulkan berbagai macam data yang dibutuhkan. Jumlah populais yang diguankan dalam penelitian ini berjumlah 30 auditor internal, teknik pengambilan sampel dengan menggunakan total sampling yang berati bahwa penentuan sampel bila semua anggota populasi digunakan sebagai sampel, sehinga sampel yang digunakan dalam penelitian ini berjumlah 30 responden. Pengujian hipotesis yang digunakan teknik analisa data rgresi linier berganda. Berdasarkan pada hasil analisa yang dilakukan dapat diketahui bahwa secara simultan dan secara parsial variabel independen dapat berpengaruh signifikan terhadap variabel dependen.

Kata Kunci: Pengetahuan; Motivasi; Independensi; Kualitas Audit.

\section{The Influence of Knowledge, Motivation and Independence on Internal Audit Quality in Rural Banks (BPR) Malang City}

\begin{abstract}
The purpose of this research was made to be able to analyze and provide facts related to the existence of knowledge, motivation, and independence can have an influence on the quality of audits in this research in the form of survey analysis method which will use questionnaires in a way to be able to collect a variety of data needed. The purpose of distributing this questionnaire to employees in this case auditors in 5 BPR Malang city with the number of auditors 30 respondents. The level of quality of data that can be generated from the user of the research instrument and evaluated by testing the validity of the data. Hypothetical testing will use multiple linear regress data analysis techniques. Based on the results of the research, it can be known that three independent variables can have a significant and positive and negative influence on the quality of audits.
\end{abstract}

Keywords: $\quad$ Knowledge; Motivation; Independence; Audit Quality.

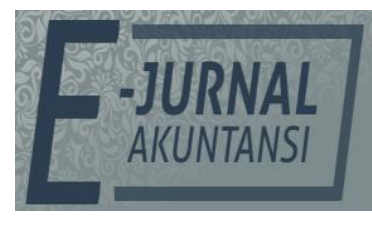

e-ISSN 2302-8556

Vol. 31 No. 5

Denpasar, Mei 2021

Hal. 1057-1068

DOI:

10.24843/EJA.2021.v31.i04.p20

PENGUTIPAN:

Nifanngeljau, J., \& Mukoffi, A. (2021). Pengaruh Pengetahuan, Motivasi serta Independensi terhadap Kualitas Audit Internal di Bank Perkreditan Rakyat (BPR) Kota Malang. E-Jurnal Akuntansi, 31(5), 1057-1068

RIWAYAT ARTIKEL:

Artikel Masuk: 22 Februari 2021 Artikel Diterima: 25 April 2021

Artikel dapat diakses : https://ojs.unud.ac.id/index.php/Akuntansi/index 


\section{PENDAHULUAN}

Pemerintah akan dituntut untuk mampu melakukan berbagai macam fungsi dalam hal ini ialah akuntabel serta transparansi dalam menciptakan pemerintahan yang bagus atau serta pemerintah yang bersih atau clean governance. Oleh sebab itu sangat memerlukan sistem pemerintaahn yang komponen dan kompleks diantaranya ialah pemerintah yang independen, memiliki pengetahuan, pendorng atau motivasi serta mempunya sistem pengendalian internal yang mana berfungsi untuk melakukan pemerikasaan, pengawasan serta dapat mengambil keputusan. Menurut Anisykurlillah, (2016) menyatakan bahwa tingkat kulaitas audit atau pemeriksaan merupakan suatu tindakan yang sangat diperlukan oleh pihak auditor independen. Pihak auditor seharusnya mempunya kemampuan untuk dapat menghasilkan sebuah laporang-laporan yang berdasarkan pada hasil pemeriksaan yang efektif serta laporang pemeriksaan yang secara wajar dan benar, serta berdasarkan pada prinsip-prinsip akuntansi yang telah ditetapkan.

Pihak manajemen sangat membutuhkan sebuah informasi keuangan untuk memahami situasi keuangan perusahaan, pengambilan keputusan dan mempermudah dalam mengelolah perusahaan. Golongan eksternal diantaranya kantor pajak, calon investor serta pihak-pihak yang terlibat dengan aktifitas perusahaan demi keberlangsungan perusahaan jauh lebih baik diwaktu yang akan datang (Futri, et al., 2014). Secara luas dikenal satandar audit yang merupakan suatu standar profesi akuntan atau yang sering dikenal dengan nama the ten generally acepted auditing satandars. Seperti yang dikemukakan oleh para peneliti-peneliti pada umumnya standar tersebut mewajibkan auditor memiliki keahlian yang seharusnya memang dimiliki oleh auditor sehingga dapat memungkinkan tugas serta tanggung jawab dapat diselesaikan lebih maksimal (Magribi, 2015).

Menurut Rosyada, (2019) menyatakan bahwa pemerikasaan yang dapat menghasilakn yang efektif tinggi, seharusnya dapat memperhatikan berbagai macam faktor diantaranya adalah tingkat independensi serta kompetisi. Jika menunggu terjadinya kecurangan baru ditangani itu artinya sudah ada kerugian yang terjadi dan telah dinikmati oleh pihak tertentu, bandingkan bila kita berhasil mencegahnya tentu kerugian belum semuanya beralih ke pelaku kecurangan (Windasari, \& Juliarsa, 2016).

Berdasarkan pengawasan audit internal yang perluh diketahui bahwa suatu perusahaan yang telah melakukan aktifitas berdasarkan tugas dan fungsinya dengan baik serta efesien dan efektif berlandasakan pada kebijakan serta ketentuan-ketentuan yang berlaku. Proses pemeriksaan yang berlangsung oleh pihak audit internal dalam melaksanakan aktifitas kadang tidak terlepas dari berbagai macam kendala seperti adanya rasa kekelurgaan, bahkan pertimbangan manusiawa dapat berpengaruh secara signifikan. Problem yang seringkali dihadapi adanya kekurangan dibagian tenaga pemeriksaan serta seluruh audit mempunyai tingkat kualitas yang tinggi, seperti auditor seharusnya mempunya jabatan fungsional, jumlah aktifitas yang di audit sama sekali tidak seimbang dengan jumlah pemeriksaan (Widyanto, 2018). 


\section{METODE PENELITIAN}

Jenis penilitian ialah penelitian kuantitatif. Populasi pada penelitian ini ialah Bank Perkreditan Rakyat (BPR) di Kota Malang. Sampel dalam penelitian ini ialah semua auditor internal BPR di Kota Malang. Tingkat keterbatasan pada penelitian ini ialah jumlah populasi, oleh karena itu peneliti membuat teknik sensus yang mana akan menjadikan semua populasi sebagai sampel penelitian. Adapun populasi penelitian berjumlah 5 Bank Perkreditan Rakyat (BPR) di Kota Malang, oleh karena itu yang akan menjadi sampel yang diambil pada penelitian ini berjumlah 30 responden. Jenis data pada penelitian ini ialah data subjek yang berupa atau sejenis opini diantaranya pengalaman, serta sikap bahkan karakteristik yang dimilki oleh orang lain atau sekelompokan orang yang akan dijadikan subyek. Sumber data dibutuhkan pada penelitian ini ialah dapat primer dan data sekunder, data akan dimiliki secara langsung dari jumlah sampel yang sudah tetapkan sehingga akan melakukan sebuah analisa data berdasarkan dengan sumber yang di memiliki dengan menggunakan kuesioner (Mardalis, 2008).

Teknik pengumpulan data dengan peyebaran kuisioner tujuannya agar tidak mengalami terjadinya kesalahan dalam memahami serta mengerti variabel yang digunakan pada penelitian ialah Kualitas Audit Internal. Kualitas audit internal ialah suatu hal yang dapat diperoleh dan sangat ditentukan oleh kepatuhan auditor terhadap SPI serta standar auditing. Pengetahuan auditor internal pada dasarnya pihak auditor internal seharusnya dapat memiliki serta dapat menentukan sumber daya berdasarkan pada satandar audit yang bertujuan untuk mencapai tujuan penugasan, yang mana berlandaskan pada karakter yang kompleks setiap penugasan. Variabel dependen yang dimuat pada penelitian ini ialah kualitas audit internal $(Y)$. Variabel independen digunakan pada penelitian ini iala pengetahuan audit $\left(X_{1}\right)$, motivasi $\left(X_{2}\right)$ dan independensi $\left(X_{3}\right)$. Instrumen Penelitian ini dapat diukur melalui skala likert, yang berarti bahwa seluruh item pertanyaan yang mana akan diukur dengan skala likert yang mana dihitung dari angka 1-5, sehingga dapat mengukur sebuah sikap yang menyatakan setuju atau ketidak setujuannya terhadap sebuah pertanyaan yang diberikan dengan skor 5 (SS), 4 (S), 3 (R), 2 (TS), dan 1 (STS). Uji validitas tujuan pengujian validitas untuk dapat dilihat sebuah ketetapan serta tingkat kebenaran pada sebuah intrumen yang merupakan alat ukur dalam penelitian. Apabila alat ukur tersebut dikatakan valid maka pada hasil pengukurannya pasti akan lebih baik, tingkat validitas dikatan sebgai sesuatu alat yang dapat dimiliki dan untuk dapat mengukur sebuah data pada penelitian. Uji Reliabilitas ialah sebuah sistem untuk melakukan pengujian yang akan berpedoman pada sebuah derajat kestabilitas serta. Untuk meakukan pengujian ini dibuat sehingga dapat dibuktikan tingkat kesamaan sebuah kuesioner telah dijawab oleh responden, atau data yang digunakan pada penelitian ini bisa diandalkan.

Pengujian Asumsi Klasik pada penelitian ini yaitu sebagai berikut; Uji Normalitas, seperti apa yang diungkap oleh (Ghozali, 2013) yang menyatakan bahwa hasil pengujian normalitas digunakan untuk dapat melakukan pengujian pada sebuah model regresi. Pengujian normalitas yang digunakan dalam penelitian ini ialah mengunakan metode kolmogorov smirnov, yang berarti bahwa tingkat signifikan jauh lebih tingggi dari pada satandar signifikan yang 
digunakan atau 0,05 dan apabila tingkat signifikan lebih besar melambangkan data tersebut dikatakan normal dalam sebuah model. Ghozali, (2013) menyatakan uji multikolinearitas digunakan untuk melakuakan pengujian pada sebuah model regresi didapatkan sebuah hubungan pada variabel independen, oleh karena itu perlu diketahui bahwa pada model regrresi yan benar adalah sama sekali tidak mengalami terjadinya hubungan diantara variabel bebas. Jika terjadi korelasi, dapat dikatakan bahwa seluruh variabel bebas yang memiliki nilai hubungan antar semua variabel yang memiliki nilai 0 . Untuk mengujinya multikolinearitas berdasarkan pada nilai VIF apabila $\mathrm{VIF}<10$ sedangkan tolerance $>0,1$ sehingga variabel tersebut dinyatakan tidak terjadinya multikolonearitas. Menurut Ghozali, (2013) menyatakan uji heterokedastisitas digunakan untuk menguji serta melihat apakah dalam sebuah model regresi terjadi ketidak cocokan sebuah varian terhadap residual satu pengamatan yang lain. Jika residual satu pengamatan ke pengamatan lain tetap sama, sehingga dikatakan terjadinya homokedastisitas maka disebut heterokedastisitas. Dengan adanya pengujian geljser siglebih besar dari 0,05 tidak adanya terjadi heterokedastisitas. Teknik analisa data yang dibutuhkan pada penelitian ini ada sebagai berikut Analisis Deskriptif bertujuan untuk melakukan analisa sebuah data yang sudah ada. Data yang sudah ada dilakukan analisis dengan langkahlangkah melakukan verifikasi data, serta melakukan perhitungan pada semua jawaban responden. Uji Regresi Berganda dalam penelitian ini, hipotesis yang diajukan pada penelitian ini ialah bertujuan untuk dapat membenarkan sejauh mana variabel independen pada variabel dependen, oleh karena itu untuk melakukan analisis regresi liner berganda dengan menggunakan rumus sebagai berikut.

$Y=\alpha+\beta_{1} X_{1}+\beta_{2} X_{2}+\beta_{3} X_{3}+\varepsilon$

Keterangan:

$\mathrm{Y}=$ Kualitas Audit Internal

$\mathrm{X}_{1}=$ Pengetahuan Audit

$\mathrm{X}_{2}=$ Motivasi

$\mathrm{X}_{3}=$ Independensi

$\beta_{1}=$ Koefisien regresi $X_{1}$

$\beta_{2}=$ Koefisien regresi $X_{2}$

$\beta_{3}=$ Koefisien regresi $X^{3}$

$\alpha=$ Koefisien korelasi

$\varepsilon=$ Error

Pengujian Hipotesisi Uji F (F-test) nilai sig 0,00 < 0,05 yang mana akan pengaruh secara simultan pada variabel dependen. Uji Hipotesis ( $t$-test). Tujuan analisa ini sehingga dapat menguji secara parsial antara variabel bebas dapat memberikan pengaruh pada variabel terikat secara baik. 1), Apabila tingkat signifikasi $<\alpha=0,05$ serta memiliki koefisien $\beta$ positif, sehingga dapat tersedia pembuktian untuk menerima hipotesis alternatif $(\mathrm{Ha})$, sedangkan hipotesis nol (Ho) ditolak. 2), Apabila tingkat signifikasi $>a=0,05$ dan memiliki koefisien $\beta$ positif, maka hipotesis alternatif (Ha) ditolak, dan hipotesis nol (Ho) diterima. 3), Apabila tingkat signifikasi $<\alpha=0,05$ dan memiliki koefisien $\beta$ negatif, maka hipotesis nol (Ho) diterima dan hipotesis alternatif (Ha) ditolak. 


\section{HASIL DAN PEMBAHASAN}

Tujuan karakteristik responden ialah untuk dapat melihat sebuah karakteristik responden yang berdasarkan pada jenis kelamin, usia dan tingkat pendidikan, oleh karena itu analisa deskriktif dapat diaktakan bahwa responden pada penelitian ini ialah laki-laki berjumlah 15 responden (50,0 persen), sedangkan perempuan berjumlah 15 responden (50,0 persen). Karakteristik responden berdasarkan usia 32 tahun berjumlah 4 responden (13,3 persen), usia 35 tahun berjumlah 10 responden (33,3 persen), usia 40 tahun berjumlah 8 responden $(26,7$ persen), usia 37 tahun berjumlah 3 responden $(10,0 \%)$, usia 44 tahun berjumlah 3 responden (10,0 persen) dan usia 47 tahun berjumlah 2 responden (6,7 persen). Karakteristik responden berdasarkan pendidikan SMA berjumlah 7 responden (23,3 persen), D3 berjumlah 3 responden (10,0 persen), S1 berjumlah 15 responden (50,0 persen), sedangkan tingkat pendidikan S2 berjumlah 5 orang $(16,7$ persen). Tabel 1, menunjuukan hasil pengujian validitas instrument penelitian.

\section{Tabel 1. Hasil Pengujian Validitas}

\begin{tabular}{lcccc}
\hline Variabel & Item & rhitung & rtabel & Keterangan \\
\hline Pengetahuan $\left(\mathrm{X}_{1}\right)$ & X1.1 & 0,589 & & Valid \\
& X1.2 & 0,551 & & Valid \\
& X1.3 & 0,618 & 0,349 & Valid \\
& X1.4 & 0,359 & & Valid \\
X1.5 & 0,680 & & Valid \\
Motivasi $\left(\mathrm{X}_{2}\right)$ & X2.1 & 0,666 & & Valid \\
& X2.2 & 0,829 & & Valid \\
& X2.3 & 0,829 & 0,349 & Valid \\
& X2.4 & 0,666 & & Valid \\
& X2.5 & 0,938 & & Valid \\
Independensi $\left(\mathrm{X}_{3}\right)$ & X3.1 & 0,484 & & Valid \\
& X3.2 & 0,899 & & Valid \\
& X3.3 & 0,899 & 0,349 & Valid \\
& X3.4 & 0,433 & & Valid \\
& X3.5 & 0,796 & & Valid \\
Kualitas Hasil Audit Internal $(\mathrm{Y})$ & Y.1 & 0,480 & & Valid \\
& Y.2 & 0,920 & & Valid \\
& Y.3 & 0,920 & 0,349 & Valid \\
& Y.4 & 0,823 & & Valid \\
& Y.5 & 0,608 & & Valid \\
\hline
\end{tabular}

Sumber: Data Penelitian, 2021

Fungsi serta maksud pengujian validitas untuk dapat melakukan pengukuran pada kuesioner yang telah diberikan terhadap responden. Apabila kuesioner tersebut dinyatakan valid apabila sebuah jawaban yang berasal dari pihak responden benar-benar dijwab dengan pertanyaan yang diberikan. Cara digunakan untuk mengukur kevalidan data pada penelitian ini ialah korelasi atau product moment serta menggunakan bevariate pearson.

Seperti telah disajikan pada Tabel 1, menunjukkan tiga variabel bebas serta satu variabel terikat yang menjadi bahan penelitian. Masing-masing variabel yang diteliti memiliki lima item pertanyaan dapat dikatakn valid. Dari setiap 
item pada setiap variabel baik itu bebas atau variabel terikat diketahui bahwa nilai rhitung $>$ rtabel dan tingkat signifikan $>0,05$, sehingga data tersebut dikatakan valid.

Tujuan pengujian reliabilitas pada penelitian ini ialah untuk mengetahui sejauh mana dapat mengukur sebuah kuesioner yang terdapat beberapa indikator dari semua variabel tersebut dapat dipercaya. Apabila terdapat kuesioner yang dikatan reliabel mengakibatkan sebuah jawaban dari responden terhadap sebuah pertanyaan ialah berprinsip serta satabil. Jika nilai cronbach alpha lebih besar dari nilai 0,06 maka hasil pengujian reliabilitas dikatakan reliabel. Hasil pengujian reliabilitas dapat dilihat pada Tabel 2.

Tabel 2. Hasil Pengujian Reliabilitas

\begin{tabular}{lccc}
\hline Variabel & Cronbach's Alpha & Role of Thumb & Keterangan \\
\hline Pengetahuan $\left(\mathrm{X}_{1}\right)$ & 0,645 & 0,6 & Reliabel \\
Motivasi $\left(\mathrm{X}_{2}\right)$ & 0,839 & 0,6 & Reliabel \\
Independensi $\left(\mathrm{X}_{3}\right)$ & 0,772 & 0,6 & Reliabel \\
Kualitas Hasil Audit & 0,828 & 0,6 & Reliabel \\
Internal $(\mathrm{Y})$ & & & \\
\hline
\end{tabular}

Sumber: Data Penelitian, 2021

Semua variabel dalam penelitian ini dinyatakan reliabel, hal ini dapat dibuktikan melalui nila cronbach alpha lebih besar dari 0,06, sehingga data tersebut dapat dikatakan reliabel.

Hasil pengujian sebuah data apa bila dinyatakan normal, apabila nilai Asymp. Sig. (2-tailed) lebih besar dari 0,05 dapat dilakuan dengan sebuh metode kolmogrof-smirnof (KS). Hasil pengujian normalitas dapat dilihat pada Tabel 3.

Tabel 3. Hasil Pengujian Normalitas

\begin{tabular}{lr}
\hline Kolmogorov-Smirnov & Unstandardized Residual \\
\hline $\mathrm{N}$ & 30 \\
Asymp. Sig. (2-tailed) & 0,200 \\
\hline Sumber: Data Penelitian, 2021 &
\end{tabular}

Berdsarkan hasil uji normalitas dapat diketahui bahwa nilai Asymp. Sig. (2tailed) sebsesar 0,200 yang berarti lebih besar dari nilai standar 0,05, oleh sebab itu data yang digunkan dalam penelitian ini dapat dinyatakan normal. Selanjutnya untuk melakukan pengujian normalitas data dengan menggunakan propability plot, berdasarkan dengan kriteria apabila pada titik-titik yang ada pada gambar atau grafik terebut menyebar mengikuti pada garis diagonal, sehingga dapat dikatakan bahwa data tersebut dinyatakan normal.

Digram tersebut diperoleh kesimpulan penyebaran data (titik) pada sekitar garis diagonal pada arah garis diagonal atau grafik, sehingga dapat dinyatakan semua data dapat berdistribusi normal serta memenuhi pada asumsi normalotis. Pengujian grafik normalitas dapat dilihat pada Gambar 1, sebagai berikut. 


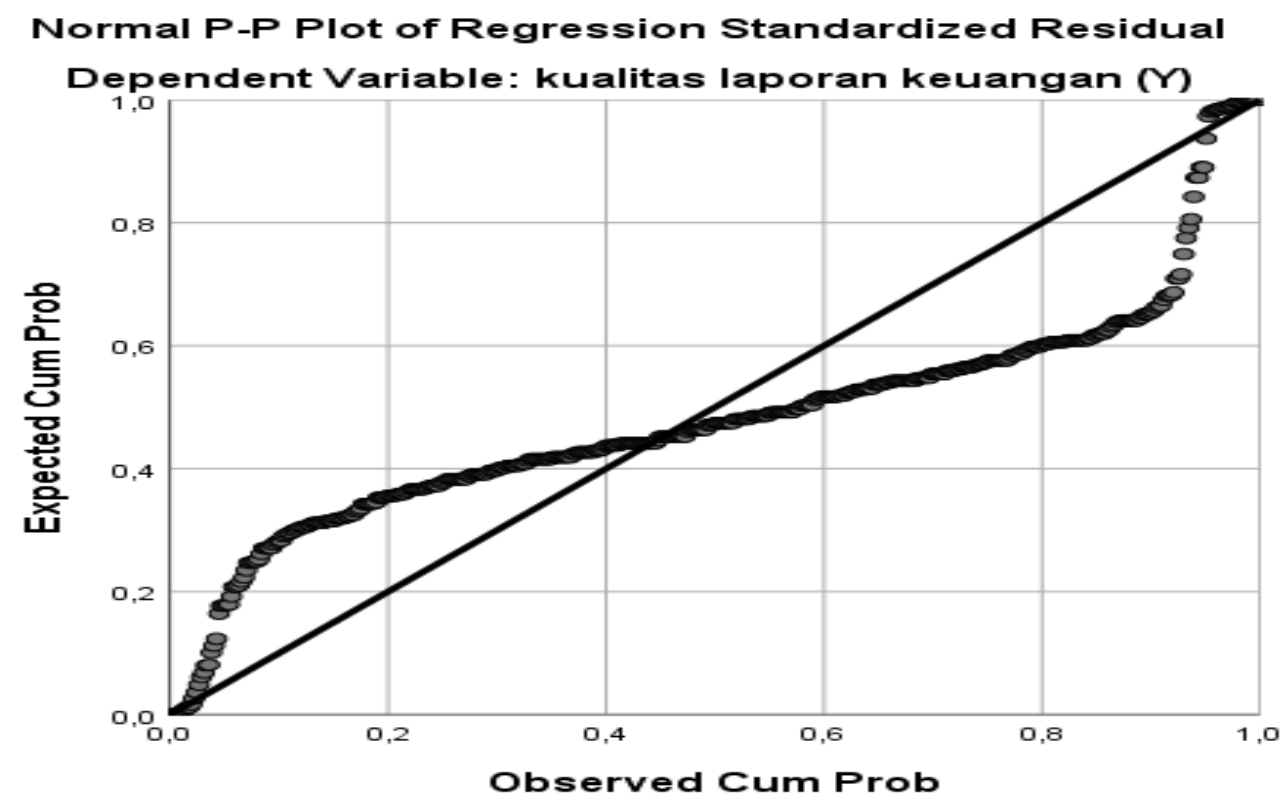

Gambar 1. Hasil Uji Normalitas Probability Plot

Sumber: Data Penelitian, 2021

Uji Multikolinieritas ini digunakan untuk dapat memastikan tidak terdapat hubungan yang kuat atau tidak ada hubungan linier, di mana hal ini di uji dengan nilai tolerance. Jika nilai tolerance kurang dari 0,1 maka terjadi multikolinearitas, sebaliknya jika nilai tolerance lebih dari 0,1 maka tidak terjadi multikolinearitas. Hasil pengujian Multikolinearitas dapat dilihat pada Tabel 4.

Tabel 4. Hasil Pengujian Multikolinearitas

\begin{tabular}{lcc}
\hline \multicolumn{1}{c}{ Variabel } & Tolerance & VIF \\
\hline Pengetahuan & 0,359 & 2,787 \\
Motivasi & 0,397 & 2,520 \\
Independensi & 0,771 & 1,297 \\
\hline
\end{tabular}

Sumber: Data Penelitian, 2021

Berdasarkan hasil yang disajikan dan dapat menunjukkan bahwa untuk semua variabel independen yang digunakan memiliki nilai VIF yang dihasilkan kurang dari 10 dan nilai tolerance $>10 \%(0,10)$ sehingga dapat disimpulkan bahwa tidak terjadi korelasi ganda (multikolinieritas) antar variabel independen. Oleh karena itu asumsi multikolinieritas telah terpenuhi.

Tabel 5. Hasil Pengujian Heteroskedastisitas

\begin{tabular}{lcc}
\hline Variabel & Sig. & Keterangan \\
\hline Pengetahuan & 0,978 & Tidak Terjadi Heteroskedastisitas \\
Motivasi & 0,315 & Tidak Terjadi Heteroskedastisitas \\
Independensi & 0,355 & Tidak Terjadi Heteroskedastisitas \\
\hline
\end{tabular}

Sumber: Data Penelitian, 2021

Berdasarkan Tabel 5, dan dapat dikatakan bahwa variabel independen pada penelitian ini yaitu pengetahuan, motivasi dan independensi menunjukkan nilai sig. masing-masing sebesar 0,979, 0,315 dan 0,355 > 0,05. Hal ini menunjukkan bahwa model regresi ini bebas dari masalah heteroskedastisitas. 
Cara menilai uji heteroskedasitas ialah dengan melakukan uji korelasi spearman yang dibuat dengan cara menghubungkan nilai denagn unstandardized residual terhadap variabel independent $\left(X_{1}, X_{2}\right.$, dan $\left.X_{3}\right)$. Hasil uji asumsi Heteriskedastisitas dapat dilihat pada Gambar 2.

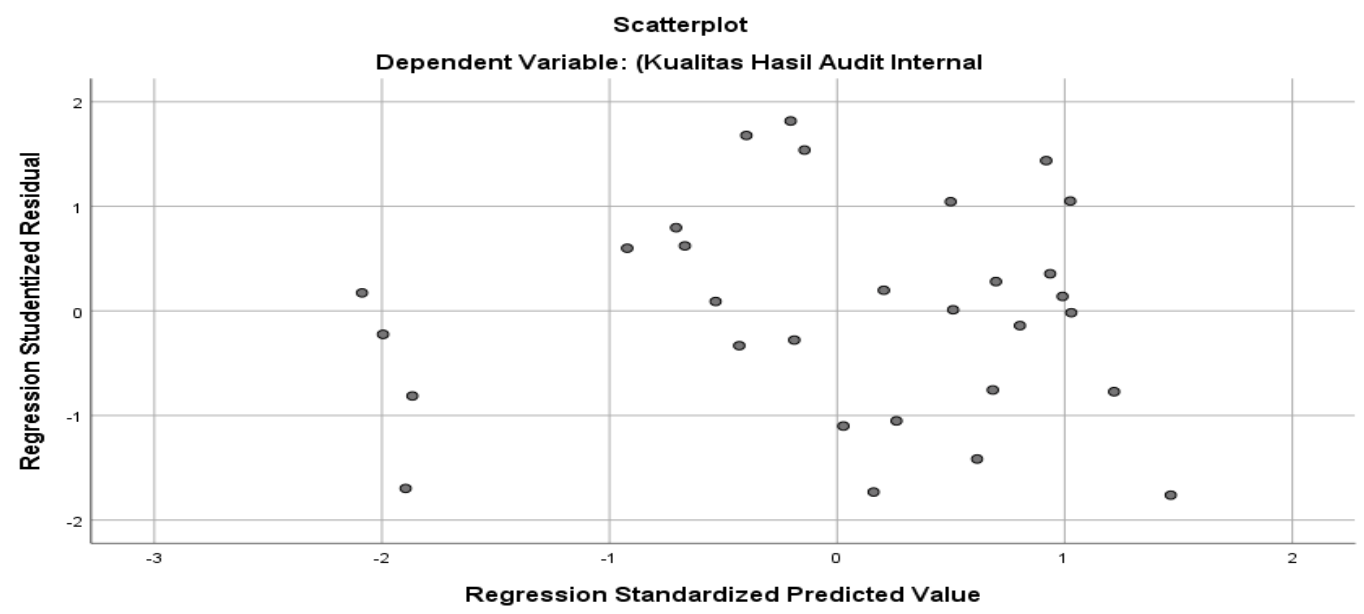

Gambar 2. Uji Asumsi Heteroskedastisitas

Sumber: Data Penelitian, 2021

Berdasarkan pada hasi scatterplot dinyatakan bahwa terjadinya penyebaran titik-titik dalam model ini sama sekali tidak sesuai denga pola yang tertentu. Penyebaran titik-titik dibawah serta diatas angka 0 dan pada gambar tersebut tidak dapat dibaca secara jelas, hasil pengujian ini dapat digaris bawahi bahwa sama sekali tidak adanya heteroskedastisitas dalam penelitian ini.

Alat analisa yang digunakan untuk melakukan pengujian hipotesis penelitian ini adalah menggunakan analisa regresi linier berganda. Tujuan dilakukan analisisi ini ialah untuk dapat melihat sebarap besar hubungan atau pengaruh variabel besar terhadap variabel (Sugiyono, 2014), untuk lebih jelas hasil pengujian regresi linier berganda dala penelitian ini dapat dilihat pada Tabel 6.

Tabel 6. Hasil Uji Linier Berganda

\begin{tabular}{llc}
\hline Variabel & Koefisien & P Value \\
\hline Pengetahuan & $-0,624$ & 0,138 \\
Motivasi & 0,346 & 0,072 \\
Independensi & 1,014 & 0,057 \\
\hline
\end{tabular}

Sumber: Data Penelitian, 2021

Berdasarkan dengan hasil pengujian persamaan regresi linier berganda menunjukan bahwa koefisien $ß$ merupakan sebuah bentuk persamaan regresi, oleh karena itu dapat dilihta pada hasil perhitungan sebagai berikut.

$$
\mathrm{Y}=4,853+0-626 \mathrm{X} 1+0,364 \mathrm{X} 2+1,014 \mathrm{X} 3+\varepsilon
$$

Berdasarkan pada nilai koefisien konstanta dapat dikatakan bahwa dalam model ini bertanda positif yang artinya bahwa kualitas hasil audit internal pada BPR di Kota Malang dalam memprediksi perkreditan mempertimbangkan Pengetahuan, pengalaman kerja, motivasi dan independensi maka pengkreditan di Bank Perkreditan Rakyat Kota Malang tetap akan meningkat. Pengetahuan memiliki nilai yang negatif artinya setiap kenaikan kepercayaan yang dimiliki audit internal, maka semakin rendah juga tingkat pengkreditan apada BPR Kota 
Malang dan sebaliknya. Motivasi bernilai positif artinya setiap kenaikan motivasi yang dimiliki audit internal, maka semakin meningkat juga tingkat pengkreditan. Penurunan motivasi serta ada pada audit internal kurang, akan disertai penurunan perkreditan di Rakyat Kota Malang. Independensi bernilai positif artinya setiap kenaikan independensi yang dimiliki audit internal, maka semakin meningkat juga tingkat pengkreditan. Pada setiap penurunan independensi yang mempunya audit internal menurun, akan disertai penurunan perkreditan di Rakyat Kota Malang

Hasil pengujian hipotesisi ini digunakan untuk dibuktikan pengujian hipotesis pada penelitian ini sudah ada, yang mana diantaranya uji $t$ dan uji $F$ disertakan dengan pengujian koefisien determinan.

Tabel 7. Hasil Pengujian Hipotesis (F)

\begin{tabular}{llll}
\hline Variabel & $t_{\text {hitung }}$ & Sig. & Keterangan \\
\hline Pengetahuan & $-4,547$ & 0,000 & Signifikan \\
Motivasi & 4,796 & 0,000 & Signifikan \\
Independensi & 17,887 & 0,000 & Signifikan \\
Fhitung & 137,093 & & \\
$\mathrm{~F}_{\text {sig }}$ & 0,000 & & \\
$\mathrm{R}$ & 0,970 & & \\
$\mathrm{R}$ Square & 0,941 & & \\
\hline
\end{tabular}

Sumber: Data Penelitian, 2021

Hasil uji hipotesis (F) dapat dapat diketahui behawa variabel bebas mampu menjelaskan terhadap variabel dependen. Dalam penelitian ini variabel bebas yang digunakan ialah pengetahuan, motivasi dan independensi secara stimultan berpengaruh terhadap variabel terikat yaitu kualitas hasil audit internal hal tersebut dapat dibuktikan melalui $F_{\text {hitung }} 137,093>$ Ftabel 3,340 dengan F sig. 0,000 dimana uji $\mathrm{F}$ yang mempunya nilai sig sebesar 0,000 yang artinya bahwa lebih kecil daripada taraf signifikan sebesar 0,05, sehingga kesimpulannya adalah Ho ditolak.

Sebagai mana pada hasil pengujian regresi linier berganda di Tebel 7, dapat dinyatakan bahwa pada variabel pengetahuan mempunya nilai $t_{\text {hitung }}-4,547$, sedangkan tingkat signifikan 0,000 yang berarti bahwa pada hipotesis $\mathrm{H}_{0}$ ditolak sedangkan $\mathrm{H}_{1}$ dapat diterima. Oleh karena itu dapat dinaytakan bahwa pengetahuan dapat berpengruh negatif serta signifikan terhadap kualitas adit internal di BPR Kota Malang. Sebagai mana pada hasil pengujian regresi linier berganda pada Tebel 7 , dapat dinyatakan bahwa pada variabel motivasi mempunya nilai $t_{\text {hitung }}$ 4,796, sedangkan tingkat signifikan 0,000 yang berarti bahwa pada hipotesis $\mathrm{H}_{0}$ ditolak sedangkan $\mathrm{H}_{2}$ dapat diterima. Oleh karena itu dapat dinaytakan bahwa motivasi dapat berpengruh positif serta signifikan terhadap kualitas audit internal di BPR Kota Malang. Sebagai mana pada hasil pengujian regresi linier berganda di Tebel 7, dapat dinyatakan bahwa pada variabel independensi mempunya nilai $t_{\text {hitung }} 17,887$, sedangkan tingkat signifikan 0,000 yang berarti bahwa pada hipotesis $\mathrm{H}_{0}$ ditolak sedangkan $\mathrm{H}_{3}$ dapat diterima. Oleh karena itu dapat dinaytakan bahwa independensi dapat berpengruh positif serta signifikan terhadap kualitas adit internal di BPR Kota Malang.

Koefisien determinasi (R2) bertujuan untuk dapat melihat tingkat kemampuan untuk dapat mengukur tingkat kemampuan sebuah model untuk 
menerangkan sebuah variasi pada terikat. Berdasarkan pada nilai R2 ialah antara 0 dan 1. Berdasarkan pada nilai R2 yang rendah malambangkan tingkat kemampuan pada sebuah variabel independen dapat mejelaskan variasi sebuah variabel dependen sangat terbatas. Nilai R2 sebesar 0,970 (97,0\%) dapat dikatakan bahwa tingkat kemampuan model pengetahuan (X1), motivasi (X2) serta independensi (X3) menerangkan variasi variabel kualitas hasil audit internal $(\mathrm{Y})$ sebesar $97,0 \%$, sedangkan 7,00\% dipengaruhi oleh variabel yang lain diluar penelitian ini.

\section{PEMBAHASAN}

Hasil analisis pada penelitian ini dapat dikatakan bahwa pengetahuan memberikan pengaruh negatif dan signifikan pada kualitas audit internal pada BPR di Kota Malang. Hal ini dapat dikatakan bahwa semakin tinggi pengetahuan yang dimiliki uadit internal maka akan semakin tinggi pula pengkreditan di Bank Perkreditan Rakyat Di Kota Malang, hal tersebut dibuktikan melalui nilai $t_{\text {hitung }}-4,547>t_{\text {tabel }} 2,051$ dan Sig $0,000<0,05$. Hasil ini sesuai penelitian hasil penelitian ini oleh (Imron, 2017) dan diketahui bahwa pengetahuan Audit, Independensi dan Pengalaman Auditor dapat memberikan pengaruh yang positif serta signifikan secara bersama-sama pada kualitas hasil audit investigasi. Hal tersebut dapat dibuktikan dari nilai signifikansi dari hasil uji $\mathrm{F}$ lebih kecil dari 0,05>0,001, sehingga dapat dikatakan bahwa pengetahuan audit, independensi, dan pengalaman auditor semakin tinggi maka kualitas hasil audit investigasi akan lebih baik

Berdasarkan pada hasil penelitian ini dapat dikatakan bahwa motivasi dapat memberikan pengaruh positif serta signifikan pada kualitas audit internal pada BPR di Kota Malang. Hal ini dikatakan bahwa semakin tinggi motivasi yang dimiliki uadit internal maka akan semakin tinggi pula pengkreditan di Bank Perkreditan Rakyat Di Kota Malang, hal tersebut dibuktikan melalui nilai $t_{\text {hitung }}-4,796>t_{\text {tabel }} 2,051$ dan Sig 0,000<0,05. Hasil ini sesuai dengan penelitian hasil penelitian ini dibuat oleh dan menyatakan bahwa (Jaya, 2017) menyatakan bahwa motivasi kerja dapat memberikan pengaruh yang positif serta signifikan pada kinerja organisasi pada lembaga perkreditan desa (LPD) Se-Kecamatan Busungbiu. Penelitian ini juga sesuai dengan apa yang nyatakan oleh (Riduwan, 2016) menyatakan bahwa variabel motivasi auditor dapat memberikan pengaruh yang positif serta signifikan pada kualitas audit. Hal ini dapat dikatakan bahwa semakin tinggi motivasi yang ada pada auditor maka akan meningkatkan hasil pemeriksaan audit atas laporan keuangan.

Hasil analisis penelitian ini dapat dikatakan bahwa independensi dapat memberikan pengaruh yan positif serta signifikan pada kualitas audit internal pada BPR di Kota Malang. Hal ini menggambarkan bahwa semakin besar independensi auditor yang dimiliki maka akan semakin tinggi pula pengkreditan di Bank Perkreditan Rakyat Di Kota Malang, hal tersebut dibuktikan melalui nilai $t_{\text {hitung }} 17,877>t_{\text {tabel }} 2,051$ dan Sig $0,000<0,05$. Hasil penelitian ini sesuai penelitian yang dilakukan oleh (Ariany, 2017) yang menyatakan bahwa pengaruh independensi auditor pada kualitas audit internal, hasil penelitian ini juga menyatakan independensi auditor dapat meberikan pengaruh yang secara signifikan pada kualitas audit internal. Penelitian ini juga bersamaan dengan 
(Susilawati, 2018) yang menyaatakan bahwa variabel independensi dapat berpengaruh positif dan signifikan terhadap kualitas audit.

\section{SIMPULAN}

Seperti yang apa yang telah dibahas pada hasil penelitian ini dan ada beberapa kesimpulan yang pelru disajikan diantaranya : (a) pengetahuan auditor dapat memberikan pengaruh negatif dan signifikan pada kualitas audit internal di BPR di Kota Malang, (b) motivasi auditor dapat meberikan pengaruh signifikan serta positif pada kualitas audit internal oleh karena itu dapat di BPR di Kota Malang (c) independensi auditor dapat memberikan sebuah pengaruh yang secara positif dan signifikan pada kualitas audit internal di BPR di Kota Malang. Berdasarkan pada penelitian ini akan sellau diharapkan untuk dijadikan sebuah bahan pertimbangan pada penelitian yang akan datang. Untuk rest-penelitian yang akan datang diajadikan wilaya semakinluas serta dapat memperluar lagi variabel bebas serta dapat mengukur dengan menggunakan variabel intervening dengan tujuan untuk dapat mengetahui variabel yang lain untuk dapat memperkuat variabel terikat.

\section{REFERENSI}

Anisykurlillah, D. A. (2016). Pengaruh Etika,Independensi, Pengalaman Audit Dan Premature Sign Off Terhadap Kualitas Audit. Accounting Analysis Journal Jurusan Akuntansi, Fakultas Ekonomi, Universitas Negeri Semarang, Indonesia, 1-7.

Ariany, V. (2017). Pengaruh Independensi Dan Kompetensi Auditor Terhadap Kualitas Audit Internal Pada Bank Bumn Di Medan. Penelitian \& Jurnal Akuntansi, 1(1), 62-69.

Futri, Putu Septiani Dan Juliarsa, G. (2014). Pengaruh Independensi,Profesionalisme, Tingkat Pendidikan, Etika Profesi, Pengalaman, Dankepuasan Kerja Auditor Terhadap Kualitas Audit Di Kantor Akuntanpublik Di Bali. Jurnal Akuntansi Universitas Udayana, 7(2), 444-461.

Ghozali, I. (2013). Aplikasi Analisis Multivariate Dengan Program Ibm Spss 21 Update Pls Regresi. Universitas Diponegoro.

Jaya, S. D. (2017). Pengaruh Motivasi Kerja, Kualitas Sumber Daya Manusia Dan Audit Internal Terhadap Kinerja Organisasi Pada Lembaga Perkreditan Desa (Lpd) Se- Kecamatan Busungbiu. Jurusan Akuntansi Program S1, 8(2).

Magribi, M.B. (2015). Pengaruh Kompetensi, Independensidan Profesionalisme Auditor Terhadap Kualitas Audit Internal Pada Bank Perkreditan Rakyat Di Kabupaten Majalengka. Jurnal Ilmiah Manajemen \& Akuntansi, 2(2), 81-101.

Mardalis. (2008). Metodologi Peneitian: Suatu Pendekatan Proposal. Bumi Aksara.

Muhamad Ali Imron, T. D. (2017). Pengaruh Pengetahuan Audit, Independensi Dan Pengalaman Auditor Terhadap Kualitas Hasil Audit Investigasi Padaauditor Inspektorat Jenderal Kementerian Keuangan. Jurusan Akuntansi, Fakultas Ekonomi Universitas Pancasila, 31(3), 165-182.

Muhammad Laras Widyanto, F. K. (2018). Pengaruh Kompetensi, Etika Dan Pengalaman Kerja Terhadap Kualitas Auditor Internal. Komunikasi Ilmiah Akuntansi Dan Perpajakan, 11(2), 165-182. 
Riduwan, N. A. (2016). Pengaruh Due Professional Care, Motivasi Auditor, Time Budget Pressure Terhadap Kualitas Audit. Jurnal Ilmu Dan Penelitian Akuntansi, 5(2), 2-16.

Rosyada, A. D. (2019). Pengaruh Kompetensi Dan Independensi Auditor Terhadap Kualitas Audit Pada Kantor Akuntan Publik Di Makassar. Jurnal Akuntansi Netral, Akuntabel, Objektif, 2(1), 128-231.

Sugiyono. (2014). Metode Penelitian Pendidikan Pendekatan Kuantitatif, Kualitatif, dan $R \mathcal{E} D$. Alfabeta.

Susilawati, N. O. (2018). Pengaruh Kompetensi, Independensi, dan Profesionalisme Auditor Internal Terhadap Kualitas Audit. Jurnal Akuntansi Bisnis, 16(1), : 42-55.

Windasari, M. Y., \& Juliarsa, G. (2016). Pengaruh Kompetensi, Independensi dan Profesonalisme Auditor Internal dalam Mencegah Kecurangan. E-Jurnal Akuntansi Universitas Udayana. 